Ein Architekturbüro, in dem nicht nur Architekten arbeiten. Über die Wertschätzung von Planung und Handwerk und einen Quantensprung im Holzbau.

\section{Aus der Landschaft heraus}

Wasser und Topografie prägen das Montafon: die Arbeit der Kraftwerke ebenso wie die lokale Architektur und das IZM.

\section{Im Rhythmus der Konstruktion}

Das System prägt den Entwurf des IZM und hebt die Holzwirtschaft auf ein neues Niveau.

\section{Einheit von Material und Raum}

Ein mehrgeschossiger Holzbau ohne innere Verkapselung. Das Holz trägt die Lasten und schafft gleichzeitig die Raumatmosphäre.

\section{Einfachheit, Transparenz, Modularität}

Der Einsatz von Holz, Stahl und Beton ist präzise und differenziert. Jedes Material spielt seine

Stärken aus.

Dr. Aldo Rota

\section{Energie und Umwelt}

Dank Passivhausstandard braucht der Betrieb nur wenig Primärenergie, das Treibhauspotenzial der Konstruktion ist gering, das Gebäude ist sozial. Gold für das IZM.

\section{Außenraum}

Natur, die mitten in der Landschaft liegt: ein Wechselspiel zwischen Künstlichkeit und Natürlichkeit.

Hermann Kaufmanns kategorischer Imperativ Ein kurzer Versuch, das Grundmotiv seines Planens und Bauens deutlich zu machen.

Otto Kapfinger

\section{Bürolayout}

Für die Angestellten bringt das neue Zentrum offene Räume und flache Hierarchien.

\section{$106 \quad$ Kunst am Bau}

Die Kunst im IZM ist mehr als bloße Zierde.

Sie schafft Identität und vereint soziale, ästhetische und kulturelle Ziele,

Dr. Verena Konrad

Facts \& Figures

\title{
Value of Work
}

An architectural firm that employs not only architects. On the appreciation of design and craftsmanship and a quantum leap in timber construction.

\section{Growing out of the Landscape}

As quintessential factors in the Montafon valley, water and topography influence the operation of the power stations, the local architecture and the IZM.

\section{In the Rhythm of Construction}

The system shapes the design of the IZM and raises the timber industry to a new level.

\section{Unity of Material and Space}

A multi-storey timber structure without inner encapsulation. Wood carries loads and characterises the interior atmosphere.

\section{Simplicity, Transparency, Modularity}

The use of timber, steel and concrete is precisely and carefully orchestrated to exploit the strengths of each material.

Dr. Aldo Rota

\section{Energy and Environment}

The passive house standard ensures low primary energy con. sumption for operation, the construction has a small carbon footprint, the building is social. Gold for the IZM

\section{Exterior Space}

Man-made nature embedded in the landscape: an alternation between artificiality and naturalness.

\section{Hermann Kaufmann's Categorical Imperative}

A brief attempt at highlighting the leitmotif of Kaufmann's design and building work

Otto Kapfinger

\section{Office Layout}

The new centre offers employees open spaces and flat hierarchies.

\section{Art in Architecture}

The artwork at the Illwerke Centre Montafon (IZM) is more than just decoration. It creates identity and meets social, aesthetic and cultural objectives.

Dr. Verena Konrad

\section{Facts \& Figures}

